Vesna Stojanović - Aleksić ${ }^{1}$

University of Kragujevac, Faculty of Economics

Bojan Krstić

University of Niš, Faculty of Economics ${ }^{2}$
ORIGINAL SCIENTIFIC ARTICLE doi:10.5937/ekonomika1604017S

Received: September 08, 2016 Accepted: October 05, 2016

\title{
KEY DETERMINANTS OF INFLUENCE IN THE PROCESS OF ORGANIZATIONAL LEADERSHIP
}

\begin{abstract}
As an organizational phenomenon that means the ability to influence followers to engage in achieving organizational goals, leadership is largely based on the ability to deliver leadership influence. The paper will consider the most important determinants of the influence of leaders on followers in the process of leadership in the organization, where we will point out the basic mechanisms of its implementation, as well as the sources of power on which the leadership influence is based, with particular emphasis on its positional and personal dimension. We will consider essential techniques of leadership influence, as well as basic factors that determine them, with special emphasis on the impact of national and organizational culture.
\end{abstract}

Keywords: leadership, influence, power, leadership process, organization

JEL Classification: L26, D23, O31, M13

\section{КЉУЧНЕ ДЕТЕРМИНАНТЕ УТИЦАЈА У ПРОЦЕСУ ОРГАНИЗАЦИОНОГ ЛИДЕРСТВА}

\begin{abstract}
Апстракт
Као организациони феномен који означава способност утицаја на следбенике да се ангажују у остварењу организационих ичиљева, лидерство се, у великој мери, базира на способности реализације лидерског утицаја. У раду ће бити разматране најзначајније детерминанте утицаја лидера на следбенике у процесу лидерства у организацији, при чему ће се указати на основне механизме ьегове реализачије, као и на изворе моћи на којима се базира лидерски утицај, са посебним акцентом на юену позициону и персоналну димензију. Биће разматране суштинске техникие лидерског утицаја, као и основни фактори који их детерминишу, са посебним освртом на утицај нащионалне и организационе иултуре.
\end{abstract}

Кључне речи: лидерство, утииај, моћ, лидерски процес, организација

\footnotetext{
${ }^{1}$ vesnasa@kg.ac.rs

${ }^{2}$ bojan.krstic@eknfak.ni.ac.rs
} 


\section{Introduction}

Leadership is the ability to influence followers to engage in achieving organizational objectives, using appropriate motivational techniques of influence based on power and formal or informal authority (Isam, Rehman \& Ahmed, 2013, p. 81). The very definition of leadership implies the fact that it is an activity that essentially relies on a process of influence, which, in turn, is based on different sources of the leadership power. The process of leadership involves a set of activities involving leaders and followers, who work together to achieve organizational goals and it refers to multidimensional relationships that can be achieved only through active participation of all relevant stakeholders in the leadership process. This implies that the process of leadership is twosided and involves a two-way mutual influence of leaders on followers, and followers on the leaders, which is why it can be argued that the leadership process is a function of three essential variables: leaders, followers and situations (Yukl, 1998; Northouse, 2008; Daft, 2011). The highlight of influence in most leadership definitions clearly indicates that it is a social process, which by no means can be one-sided. What makes its essence and represents a fundamental mechanism for its operation, without which, in fact, we could not talk about the phenomenon of leadership, is precisely the process of influence, which represents the core of the leadership process, because mobilization and commitment of followers is being realized through it (Stoner, Freeman, 1995).

The mechanisms that ensure the influence of leader and the support of followers are a source of controversial opinions of theorists, resulting in the different definitions and diverse theoretical concepts that interpret the phenomenon of leadership. It is these mechanisms, their sources and factors that will be the subject of this paper.

The aim is to highlight the importance of the phenomenon of influence in the leadership process, the specific tactics of leadership influence, the factors that affect influence, as well as the most important sources of power on which the influence of a leader is based. Consequently, the aim is to draw the attention to the fact that the quality of the leadership process, in addition to the characteristics of leaders, followers, and the peculiarities of the situation, is significantly caused by specific mechanisms for achieving leadership influence.

In this study, qualitative methodology was applied. It was based on a descriptive study, comparison and interpretation of scientific achievements identified as relevant within a defined problem area, in order to synthesize the different positions, based on which the general conclusions about the significance of the influence of the leadership process were derived. Theoretical verification was achieved by applying the method of analysis, synthesis, deduction and induction, with the aim to come to the adequate general conclusions by abstraction and generalization.

Bearing in mind the object and purpose of the research, after introductory remarks, the paper is divided in four parts. The first part deals with the essence of leadership influence, followed by the second part where the most important sources of power on which the influence of leaders is based are pointed out. Thereafter, the third part provides an overview of the most important tactics of leadership influence, while in fourth part we consider the impact of national and organizational culture on the selection of tactics of influence in the process of organizational leadership. 


\section{The essence of leadership influence}

The influence is any action or behavior that leads to changes in attitudes or behavior of another person or group (Yukl, 1998).

An important feature of any leadership process is that it always takes place in the context of certain groups and the specific situation, and in this light to be seen, the different aspects of leadership influence should be considered. There is no doubt that this is an extremely subtle phenomenon, which, despite many years of research is still not fully understood. One theory, which is often used to explain this process, is a theory of exchange, which sees leadership as a process in which a specific exchange of benefits between leaders and followers is performed (French, Bell, 1999, p. 284). Depending on the position in the exchange, superior and inferior actors are formed, and therefore one party will be able to realize a position of power and influence other actors in exchange. The benefit of the exchanges may be tangible or intangible (psychological, emotional) value, and is defined depending on the situation, which made frequent attempts to explain the process of leaders' influence on the other actors based on psychological categories. This is quite acceptable if one takes into account the fact that both sides of this process are people with different cognitive schemes and psychological characteristics. In this regard, nowadays the so called "emotional aspects" of leadership influence are very present. These aspects assume that the leader-follower relationship is often difficult to explain rationally, and more likely connected to emotional reasons (Hollander, 2000). Among the psychological theories that attempt to define and explain this relationship, the theory of identification occupies the special place, indicating the human need to identify with other people, especially with the members of the group, in certain situations, which is listed as one of the determining factors for the design of the leadership process (Hollander, 2000). The questin of who will be singled out as the person who can exercise influence over others in this process, i.e. as a leader, depends on many factors and many situational variables.

As a very important component of leadership process, the influence is a complex category. There is no doubt that the level of influence is closely correlated with the amount of power that a leader possesses. However, since the model of influence includes other components, it can be concluded that power is only a potential for a leader to influence the behavior of certain social actors. The degree of effectiveness of the entire leadership process depends on the extent in which this potential will be realized. This is because an attempt to influence can result in three basic types of reactions (Du Brin, 1997):

1) Acceptance and commitment - the person that is an object of influence agrees with the decision or request of the other person and makes great efforts to implement the requirements or enforce the decision. From the standpoint of one who seeks to influence, this is the most desirable outcome.

2) Compliance - a person is ready to do what is required, but does that reluctantly and with minimal effort. This is about the impact on the behavior, not the attitudes of target actors who agree to implement the decision, although they are neither convinced of its accuracy, nor the positive effects of its application.

3) Resistance - the target person is not ready to accept the demands of leaders and actively trying to avoid or sabotage them. In this case, it is difficult or completely impossible to achieve effective influence. 
Understanding the essence of the process of influence is associated with basic psychological categories (which often explain the leadership process in whole), such as instrumentalization, internalization and identification, which also serve to highlight the different mechanisms of leader's influence on followers (Hollander, 2000).

Instrumentalization is based on compliance with the requirements in order to achieve the desired benefits (rewards) or to avoid penalties controlled by a person who makes an influence (the leader), where, as already mentioned, both categories can be tangible or intangible (Yukl, 1998; Shamir, House \& Arthur, 1993). Basic driving forces of this behavior are purely instrumental in nature, and are related to practical reasons, primarily, rational behavior directed towards an attempt to avoid punishment or gain a reward.

The process of internalization is based on the commitment of followers who are willing to carry out the requirements of leaders, because these requests are internally desirable and aligned with their own values, beliefs and personal preferences. In this case, the requirements are integrated into the dominant system of values of people who are targeted, which is why they are ready to implement them, regardless of the expected benefit (or detriment) (Shamir, House \& Arthur, 1993). Thus, internal motivation is affected and people are encouraged to focus on the internal incentives, such as self-expression, advancement and self-respect, but that it is not contrary to the interests of the organization. At this stage, the values compatible with the value system of followers are being attributed to the leader, after which the leader is perceived as someone similar to the followers, and therefore worth of engagement and investment of energy by followers, thus paving the path for the realization of leadership influence. This variant of attribution is known as "egocentric attribution", and refers to the natural tendency of every individual to better evaluate people estimated similar to themselves, on any criterion (sometimes even by attributes related to physical appearance) (Bowditch, Buono \& Stewart 2008; Janićijević, 2008).

The process of identification refers to the identification of target people with those who exert influence, whereby the fulfilment of demands occurs as a result of the desire for acceptance and respect. The influence exerted in this way can be achieved deliberately or spontaneously, although it is very strong in both cases, given the strong psychological triggers that make up its surface. This type of influence is especially peculiar to charismatic leadership, which is based on the strong appeal of leaders to followers and their need for approval and acceptance by the leaders (Bowditch, Buono $\&$ Stewart, 2008). Personal identification with the leader of one of the key elements in leadership development and is present in the majority of followers, and especially in the type of followers with the problems of personal identity, low self-esteem and a high need for dependence on authority. Equally important is the process of social identification, which includes tendency of people to define themselves primarily through membership in a particular group or organization, seeing it as an important part of their social identity (Yukl, 1998; Shamir, House \& Arthur, 1993). When the social identification is extremely high, people are willing to subordinate their individual needs to the group ones, sacrificing personal interests in favor of the group and the leader. Followers attribute to the leader those traits that they perceive as desirable, irrespective of whether the leader really possess them or not. Effective leaders are able to increase the level of social identification, and thus their influence, in different ways (for example, by giving a group of specific features, symbols, rituals, making it so different from other groups). 


\section{The power in the leadership process}

As an instrument that a leader uses in the process of establishing the influence on the followers, the power is one of the key aspects of research on the phenomenon of leadership „Power is a potential ability to change behavior, course of events, to overcome resistance and force people to do things they otherwise would not do. „, (Senior, 1997, p. 152).

Like leadership, power is obviously a social category and is manifested in the process of group dynamics, which is why it is considered to always be a function of certain social relations. It is not absolute, but relative category, which depends on how it is perceived by different social constituents, as well as what its primary sources are. Despite the fact that the literature identifies a number of sources of power in the organization, it can be concluded that, basically, the power derives from two main sources: from the position that a person occupies in the organization, or the attributes related to its holder and the connections that are established in the superior - inferior relations (Yukl, 1998).

It is known that the classical organizational theory recognized formal authority as the sole source of power. This type of authority is based on the perception of the duties and responsibilities that are inherent to a specific position in the organization, and includes the right of those who occupy a given position to influence certain aspects of the behaviour of members who work in other organizational positions, mainly via manipulation of rewards and punishments. Early studies of organization suggested that formal authority springs from tradition and that it is legalized through customs, practices and beliefs that certain positions in the organization carry a natural right of their holders to affect people in other positions, in the form of command, establishment of rules, requirements and expectations that these requirements are met (Senior, 1997, p.152).

Although it is specified in organizational chart, job description or other official document, the degree of leader's influence arising from positional power will be much stronger if his selection is supported by the majority of organizational members. Also, the intensity of the influence will be much greater if the values of leader are compatible with the values of followers or with generally accepted social norms. Otherwise, the formal authority based on position will be sufficient to secure a short-term impact, which cannot be regarded as a good basis for the realization of leader's power.

The second group of sources consists of different types of power that do not arise from the formal position that a leader occupies in the organization, but from his personal characteristics. One of the most important sources of personal power stems from the expertise or the ability to solve specific problems and carry out tasks in the organization. What is important for this kind of power is that it is not absolute, but relative, which means that it often does not depend on the real but a perceived amount of knowledge and information compared to other professionals in the organization and outside of it, so sometimes a little extra expertise, can bring a large volume of power and influence, and vice versa (Yukl, 1998). This is the so-called reputational aspect of expert power, which is based both on the actual amount of knowledge shown in critical situations, and the follower's idea of the leader's knowledge and expertise (Yukl, 1998). Expert power is an integral component of professional credibility and is closely linked to other forms of leadership power, which is called the power of emulation or referent power (Handy, 1993). This form of power largely correspondes to the process of leadership, and is based 
on the desire and willingness of people to comply with the requirements of those entities that they admire and feel attracted to. As mentioned, a particularly powerful form of leadership power is reflected in the process of personal identification, in which followers who identify with the leader strive to be accepted and imitate his behavior, so a leader who is accepted can make a significant influence by promoting their own behavior as an example to be followed. Referent power is a subtle form of power and is based on the psychological impact of leaders and feelings of attraction and loyalty that develop gradually over a longer period of time.

Modern literature, with a certain critical review of traditional theories that explain the phenomenon of power, points out the invisible or hidden sources of power and influence. It is believed that most of the sources of power are in some way connected with the process of decision-making, whereby the power is explicitly being manifested by imposing the alternative that best suits those who have the most power. In this way, in direct confrontation in the process of solving problems, it is possible to clearly observe who the key holders of power in the organization are. Another aspect of power is reflected in the fact that certain solutions are imposed out of the decision-making process, so placing a question on the agenda is not allowed at all, or that a certain group of people is excluded from the decision-making process, whereby their leader presents its solutions as the only ones correct and acceptable, but without the use of visible force. This practically refers to the power of creating awareness, ideas and attitudes of followers in order to perceive the beliefs and attitudes of a leader as their own. Although this form of power is treated separately and is usually called interpretive power (Janićijević, 2008), it must be based on one of the other sources of power, so it should always be considered in the context of the position or the personal characteristics of leaders.

In the context of the strategy of increasing the power of a leader in the framework of the political process, there is a question of balancing its structure, or a combination of different sources and forms of power, as well as the question of the quantity of power necessary for the realization of the desired impact on followers. Although it is now considered that the ideal solution is a combination of positional and personal power, the classical theory of organization and management advocated the idea that positional power sources provide long-term opportunities and stronger influence. Over time, these stances have been misinterpreted and brought to the counterfeits, so in a large part of modern civilization some kind of aversion to positional power has been developed, which has become synonymous with the threat, fear and manipulation. It is necessary, however, to emphasize that the positional power is extremely important, not only as a significant source of influence, but also because it can be used to increase personal power leader, and create conditions for its implementation (Yukl, 1998). So, for example, control of information complements the expert power, based on technical skills and other skills, while the power of rewarding facilitates the development of deeper relationships among the members of the organization and can increase the referent power of a leader. A certain amount of power of punishment is needed to support the legitimate and expert power where necessary to ensure compliance with rules and procedures, which are unpopular, but necessary to perform a specific task and for the successful functioning of the organization.

However, regardless of necessity, excessive level of positional power can be counterproductive and even detrimental. Leaders who have their influence based solely on positional power often miss other opportunities to exercise influence on followers. 
It sometimes happens that leaders with strong positional power tend to turn such power into domination and exploitation of subordinates, as in some national cultures led to the formation of the saying that "power corrupts", which primarily relates to the power of the position. On the other hand, personal power provides less opportunity for abuse, due to the fact that the impact based on this source of power can quickly be eroded if the behavior of a leader is not in line with the expectations of followers.

Given the fact that the influence is primarily based on power, it may be seen that each of the above influence processes has its stronghold in one of the typical sources of power: the instrumentalization is linked to the power of punishment and reward, internalization, mainly to the expert power and power of information, while identification is primarily based on the referent power. It should be noted that the aforementioned processes are not mutually exclusive, but they complement each other in an ideal situation.

The amount of overall leader's power that is necessary for the realization of the influence depends on several factors, of which two are the most important (Yukl, 1998):

1) The objectives to be achieved or the requirements of the situation in which the leadership is manifested;

2) Leader's ability to use the available power effectively.

Certain circumstances require more leadership power than others. A typical situation is related to the process of organizational change. A large amount of power is particularly necessary when there is a strong obstruction of changes, and when a long period of their implementation is expected, with no significant short-term results. These situations require activation of combined sources of power, and very often the application of different political processes and strategies, with the main intention of all holders of power reduced to its use for the exercise of leadership influence - substantive variables are directing the behavior of followers in the desired direction.

\section{Basic tactics of leadership influence}

Many years of practice have shown that more than one technique can be used in order to exercise or increase leadership influence. The most important techniques are the following: (Falbe, Joun, Yukl, 1993):

- Rational persuasion,

- Inspirational appeal,

- Integration,

- Exchange tactic,

- Personal appeal,

- Pressure tactic and

- Participation.

Rational persuasion is one of the traditional techniques of influence, and is based on the use of logic, facts, and arguments for the persuasion that a particular proposal or a request is the best way to achieve a certain goal. This technique provides the best results when the person to whom the influence is directed shares the same goals with the leader. The expert knowledge and rhetorical skills of leaders create a base from which the arguments that underpin the power of persuasion and influence on followers arise. 
Unlike the logical and rational arguments, technique of inspiracionog appeal relies on emotions and personal values. It focuses on the development of enthusiasm and commitment, by fostering strong feelings, connecting requests or suggestions to the needs, expectations, desires or ideals of the target entity. The nature and content of inspirational appeal and the manner of its presentation depend on a series of incentives that serve as the driving force behind the behavior of leaders and followers (Green, 2008). In addition, its structure is caused by the complexity of the problem being solved, the risk level and the degree of deviation from the regular, everyday activities. The effective application of these techniques requires knowledge of the system of values, desires, beliefs, fears, emotions, etc., and the whole complex of factors that make up a psychological profile of a subject to which the influence is directed.

The exchange tactic is based on the implicit or explicit offer of rewards in exchange for obedience to a particular request. It is useful especially when the target person is indifferent or unwilling to accept a particular task, because its implementation requires great effort and does not offer any significant benefit. An essential prerequisite for its implementation represents a control of potential sources of remuneration which can be very diverse, and whose use is again conditioned by various factors motivating the person to whose behavior the influence is directed.

Personal appeal is the technique of influence, which is based on friendship and loyalty. Compliance with the requirements of the leaders in this case is motivated by purely personal attractiveness to the leader and a sense of closeness and loyalty by followers, which proceeds from the mutual friendly relations, and most commonly, informal relationships. The integration tactic is closely connected with the personal appeal. It is designed to develop a positive attitude towards the person who makes an influence, where giving compliments and doing extraordinary, often unexpected services, as well as show respect and friendly behaviour are the key means. If this kind of leader's behavior is perceived as genuine, it can lead to the formation of positive attitude of the target person towards the leader, which will result in a greater willingness to accept the influence. However, if applied directly before trying to influence, it can be perceived as manipulation and have the opposite effect, which is why this technique is significantly more effective as a long-term, than as a short-term strategy of influence.

The pressure tactics include threats, warnings and coercion, in order to ensure compliance with the requirements of a leader. Although there is a threat of conflict and adverse reactions in the form of obstructive behavior, there are cases where this technique is the preferred alternative, necessary to ensure discipline and respect of important rules and procedures on which the survival of the organization depends (eg. safety regulations). However, the pressure tactic by no means should become the dominant way of achieving influence in the leadership process.

In recent years, particularly popular influence tactic is related to the participation. It is based on the inclusion of the target person in the decision-making process, which increases their motivation and involvement in the implementation of those decisions. It is based on the fact that the size of the influence is not fixed, but rather a variable category, which can be divided between two or more individuals (Kelly, 2012). It is believed that the process of participation increases the weight of the overall influence of the leadership process, and, consequently the ability of a leader to influence the behavior of other actors of the process. This tactic figures as the foundation for the creation of modern leadership 
styles that place the emphasis on the division of power, authority and responsibility, which will be discussed later.

Evident correlation of power and influence, in the light of the selection and effectiveness of certain tactics, can be manifested in several key directions (Falbe, Joun, Yukl, 1993):

1) The dominant form of power that a leader possesses, directly determines the choice of tactics of influence that will be applied in the leadership process. The use of certain tactic is caused by specific types of power that are conditio cine qua non of application of the most techniques of leadership influence. So, for example, the technique of rational persuasion requires the presence of expert power, the exchange tactic requires the power of remuneration, and the pressure tactic requires the power of punishment. It must be noted that in most cases for exercising influence the perceived power is much more relevant than the real power of the leader. Therefore, it is important to convince the target person that the leader has a certain power and that he can use it, regardless of whether it matches the real situation or not.

2) It is possible that the power of the leader acts as a moderating factor in the influence process, increasing or reducing its effect in situations where the application of certain tactic is not directly associated with certain types of power as in the previous case. For example, a leader with high referent power will be able to achieve greater success in the implementation of techniques of rational persuasion than someone who does not possess this type of power, regardless of the fact that this technique is not directly related to the referent, but to the expert power. Also, a strong expert power can significantly strengthen an attempt to influence, even in cases where the expertise of leaders is not a primary factor for stimulating specific alternative choices.

3) There is a possibility that the power of a leader influences the response of individuals, even if the leader does not intend to exercise any influence on the behavior of that individual. People tend to behave much more polite and agreeable to the people who have significant power of rewards and punishments, which is manifested even when there is neither the direct dependence on the holders of this type of power, nor their ability to directly use it. The point is that people perceive the potential effects of such behavior and the possible reaction of the leader in the future and accordingly adapt their current acts, which in the end results in an influence that a leader is not even aware of.

Certain studies have shown that some of the tactics of leadership influence are more efficient in one than in other situations (Du Brin, 1997). So, for example, inspirational appeal and pressure tactics produce the best results when used in a top-down variant; personal appeal and exchange tactics are more successful in lateral relationships, while rational persuasion tactics are the most effective when applied to the lower organizational levels.

\section{The impact of national and organizational culture on leadership influence tactics}

The choice of tactics of leadership influence and dominant sources of leadership power are influenced by the characteristics of national and organizational culture within which the observed organizations and their leaders are functioning. It is known that all national cultures may vary in relation to the four primary dimensions (Hofstede, 2001): 
Individualism versus collectivism identifies whether the culture dominantly reflects an individual or a group. Individualism means weak social ties and social structure in which the individual cares only for self, they early become independent from their primary family and they are considered to be responsible for their own destiny. In collectivist cultures, people are attached to the collective, often to the extent that their own identity is experienced only through a social community. The members are loyal to the group, which is expected to protect and help them, and in turn they provide maximum support whenever necessary. In individualistic cultures, individuals are responsible for making decisions, whereas in collectivist culture the responsibility is shared by the group members. In collectivist cultures, there is a much greater tendency for group members rely on the authority of the position in the decision-making process, which is why the influence of leaders is more based on positional, rather than on personal sources of power.

Power distance describes the extent to which a society accepts that power in institutions and organizations is distributed unequally (Hofstede, 2001, p. 340). In cultures with higher power distance, there is a dominant view that the unequal distribution of power is natural and desirable or necessary for the functioning of society. In these societies the authoritarian consciousness prevails, the degree of centralization is higher, and the organizations are characterized by clear hierarchy, formalized structures and unquestionable obeying to the people in the positions of power. In contrast, in the cultures with low power distance, there are aspirations for greater unification of power among members of society. Those who have the power - try not to expose it, the decisionmaking is decentralized on all the levels, while the organizational structures are more flexible, less rigid and inclined to informal models of structures, favoring personal power of the leaders.

Uncertainty avoidance identifies the willingness of members of a culture to accept uncertainty, risk and change. National culture with a high degree of uncertainty avoidance is characterized by an extremely low tendency for people to change in the private and professional spheres, fear of everything new and unknown and low tolerance of differences on any grounds. In these cultures there is a pronounced distrust of individuals and groups who in any way deviate from standard behavior patterns, as well as of those who belong to other national cultures. As a result of such attitudes, organizations in cultures with a high degree of uncertainty avoidance are based on a number of formal rules to regulate the behaviour of employees, standardization and formalization, in an attempt to provide as much stability and predictability, which is why those organizations incline to a greater use of positional power and tactics of leadership influence based on it.

Masculine versus feminine values in the literature are often defined as the quantity versus quality of life. In cultures with a predominant masculine values, there is a dominate need for achievement, success and acquisition of material goods, which are the basic criteria for the assessment of one's capabilities and value. In contrast, in cultures with prevailing female values, there is a dominant need for social contacts, providing support and assistance, the development of harmonious interpersonal relationships, respect and dignity. In these cultures, power is based more on personal than on the positional sources of power.

Besides to the characteristics of national culture, the choice of tactics of leadership influence and the dominant sources of power is also influenced by organizational culture. Organizational culture as a system of common values, attitudes and ways of thinking 
shared by employees of the organization (Bratton, Gold, 2003, p. 485) defines a set of beliefs and assumptions about how employees should behave, what is important for the organization and how it should be positioned in relation to the environment (Eric Nielsen, 2015). Organizational culture consists of its dominant values, and, from that point of view, can extract as many cultures as there are types of different systems of values and beliefs (Cooke, 2003). One of the most famous classifications of organizational cultures is one given by Harrison and Handy, who divided all cultures into four types: power culture, role culture, task culture and person culture (Petković, Janićijević et al. 2014). Each of these types of culture promotes the domination of some sources of leadership power, and therefore the basic sources of leadership influence.

Power culture is neither based on rules and procedures, not burdened by bureaucracy, so the decisions may be made very quickly. This culture is mainly present in a small organization, although it can be found in the organizational units of the larger systems. The system relies on the central figure of the leader, who is the holder of power, resulting in a structure that is able to rapidly change in an attempt to respond to external challenges. Communication is intense and informal, and political processes and the struggle for power are very pronounced and strong. The autocratic leadership, in which the resource control or personal charisma is a main source of power of a leader, is most commonly applied.

Role culture is often referred to as bureaucratic, because there are clearly defined procedures of behaviour, formal rules, standards and descriptions of roles. It is based on logic, reason and rationality. The power of a leader ensues from the position and is generally depersonalized. This is an organization with clear hierarchical levels and inclined to centralize decision-making. Its advantage is the predictability and stability, while the disadvantages are reflected in inflexibility, inertia, tightness and slow response. This culture creates a highly structured, stable organization, bureaucraticly accurate job descriptions and roles of individuals, in which work is controlled through procedures and rules which are far more important than the person who applies them.

Task culture is based on the assumption that solving problems is the purpose of the organization. The emphasis is on results and how to get the job done in the best possible way. Individuals have broad discretion and control over the work they perform. This culture is flexible and adaptive. The organizational structure is often based on teamwork, flexible and can be transformed depending on the current task. The organization does not have such solid and clear boundaries between the segments as is the case with the role culture. The power of a leader stems from expertise, so much more from the knowledge than from his position. Performance is viewed in terms of results achieved and problems solved, and the success and achievement are the most appreciated values. Talent, creativity, team problem solving and cooperation are also favored.

Person culture favors the interests and goals of the individual who is the central figure in the organization, which exists precisely to serve as a support to other individuals. The highest value of the organization is the person's autonomy and its members believe that they are, in a sense, superior to the organization. Individual goals dominate the organizational ones, so that the survival of the organization can be difficult and uncertain, which is why this culture is rarely present in the entire organization, but rather can be found in its smaller parts. It is characterized by a small number of rules and procedures, is extremely decentralized when it comes to decision-making, there is a wide dispersion of power and insistence on individual freedoms. Given that the source of power lies in the competence and inventiveness 
of employees, the advantage of this organizational culture may be in creativity and innovation, which is why it is usually related to scientific research institutions.

\section{Conclusion}

One of the primary characteristics of the process of leadership is to be largely based on the influence that is being realized with the use of any source or a form of power. The power is an instrument used by the leader in order to establish the influence on followers. Regardless of whether it is a positional or personal dimension, the power is an essential component of the analysis of any leadership process.

Given the fact that the amount of leadership influence is not a fixed category, it can be increased by using different tactics, depending on the specifics of the situation. It can therefore be concluded that the influence of a leader is a specific contingent variable, which is formed under the impact of various situational factors, but there are circumstances that require a combination of multiple tactics of influence and more sources of leadership power, and one of those situations is connected to the context of organizational changes, which are an essential precondition for the survival and functioning of the organization in the modern environment.

The scientific contribution of this work, in theoretical terms, is reflected in the emphasis on the importance of research of the phenomenon of influence and power in the leadership process, as well as in highlighting the role of various factors in the choice of tactics of leadership influence and giving benefits to certain sources of power, in the process of organizational leadership. Theoretical approach synthesized in the paper is the basis for possible future theoretical and empirical research, and its practical contribution is reflected in provision of the guidelines for leaders in the organizations in order to more actively consider the effects of certain tactics of influence, power sharing and their adjustment to the requirements of specific situational circumstances.

The fact is that the tactics of leadership influence, with the support of the power that makes their essential back-up can lead to routing the behavior of followers in the desired direction, and to inspire people to engage in achieving a certain goal, which is the essence of leadership process. The extent of this influence and manner in which people respond to an incentive or an influence attempt, depends primarily on the degree and nature of their motivation. Therefore, the motivation can be considered as the third link in the chain of leadership process, which is very important, and future research will be aimed, inter alia, to this problem area.

The biggest limitation is reflected in the lack of empirical research that would explore the effects of certain tactics of influence, in the context of cultural and organizational specifics of domestic enterprises, and examine concrete relations of influence in the process of leader-member exchange in organizational leadership in our country. It is evident that the process of leadership in organizations cannot be carried out independently of the application of power, and that the effectiveness of the overall leadership process is largely conditioned by the strength and the form of the leader's influence on the followers. In this context, we should expect an increasing number of empirical studies in this problem area, which will be one of the directions of future research of the author of this article. 


\section{References}

Bratton, J., Gold, J. (2003). Human Resource Management: Theory and Practice, Basingstoke, USA: Palgrave Macmillan.

Bowditch, J., Buono, A., Stewart, M. (2008). A Primer on Organizational Behavior, $7^{\text {th }}$ edition, New York, NY: Wiley.

Cooke, R.A., Szumal J.L. (2003). Measuring Normative Beliefs and Shared Behavioral Expectations in Organizations: The Reliability and Validity of the Organizational Culture Inventory, Psychological Reports, Vol.3, No. 2, pp. 1299-1330

Daft, R. (2011). Leadership: Theory and Practice, Forth North, USA: The Dryden Press

Du Brin, A. (2015). Leadership: Research Findings, Practice, and Skills, New York, NY: Wiley.

Eric Nielsen, J. (2015). Corporate entrepreneurship, organizational learning and knowledge implementation. Economic Horizons, 17 (3), 2013-217.

Falbe, C., Joun, J., Yukl G. (1993). Patterns of Influence Behavior for Managers, Group and Organization, Management $\mathrm{N}^{\circ} 18$, pp.208-224.

French, W., Bell, C. (1999). Organization Development, New York, NY: Prentice-Hall

Green, C. (2008). Leader member exchange and the use of moderating conflict management styles: Impact on relationship quality. International Journal of Conflict Management, 19 (2), 92-111.

Handy, C. (1993). Understanding Organizations, London, UK: Penguin

Hofstede, G. (2001). Culture's consequences, Thousand Oaks, CA:Sage Publications

Hollander, E. (2000). Contemporary Trends in the Analysis of Leadership Process, New York, NY: Irwin

Isam, T., Rehman, S. \& Ahmed, I. (2013). Investigating the mediating role of organizational politics between leadership style and followers' behavioral outcomes. Business Strategy Series, 14 (2/3), 80-96.

Janićijević, N.(2008). Organizaciono ponašanje, Beograd: Data status.

Kelly, R. (2012). The Power of Followership, New York, NY: Doubleday

Northouse, P.G. (2008). Leadership: Theory and Practice, Massachusets: Sage Publications Inc

Petković, M., Janićijević, N., Bogićević Milikić, B., \& Aleksić, A. (2014). Organizacija preduzeća, Beograd: Ekonomski fakultet.

Senior, B. (1997). Managing Change, New York, NY: Prentice-Hall

Stoner F., Freeman, R. (2009). Management, New York, NY: Prentice-Hall

Stojanović Aleksić, V. (2016). Sledbenici u procesu organizacionog liderstva: od atribucije do podeljenog vodjstva, Ekonomski horizonti, Maj-Avgust 2016, Vol. 18, sveska 2, str. 139-151.

Shamir, B., House, R., \& Arthur M. (1993). The Motivational Effects of Charismatic Leadership: A Self-Concept Based Theory, Organization Science, Vol. 4, 1993. 1-17.

Yukl, G. (1998). Leadership in Organizations, $8^{\text {th }}$ Edition, New York, NY: Pearson Education. 